\title{
DISCUSSION
}

\section{EXPERIMENTAL STUDIES TO CONSTRAIN PARENTAL MAGMA OF MALANGTOLI VOLCANICS FROM SINGHBHUM CRATON OF THE EASTERN INDIAN SHIELD by}

\author{
Mousumi Banerjee and others. Jour. Geol. Soc. India, v.88, 2016, pp.245-255.
}

Shabber Habib Alvi, Department of Geology Aligarh Muslim University, Aligarh -202 002, comments:

The geological setting of the reported Malangtoli lavas is ambiguous in the stratigraphic sequence proposed by Saha (1994) because of the consideration of Iron Ore Group as single tectonostratigraphic unit (Dunn, 1966, p.17). Perhaps the reported lavas are part of Bonai range volcanic rocks which are occurring as sub-aerial rocks in the east and sub-marine rocks in the west. They have been considered older than the Paleoproterozoic Noamundi-Koira BIF sequence (Bannerjee, 1982) and on the basis of field evidences, I am sure that they are not overlain by Kolhan Group or equivalent sediments. Kolhan Group overlies the Jagannathpur volcanic rocks (Banerjee, 1982).

The reported Malangtoli lavas contain pyroxene of diopsidic augite composition and plagioclase oligoclase composition. Most of the samples have more than $10 \%$ normative quartz and more normative hypersthene than the normative diopside which is a characteristic of calc-alkaline series rocks. Pyroxene of diopsidic augite composition and plagioclase oligoclase /andesine composition is also reported from Jagannathpur volcanic rocks. Alvi and Raza (1991, 1992a, 2004) have reported boninitic/high-Mg andesite affinity of the samples collected from the Jagannathpur volcanic suite which unconformably overlies the Noamandi-Koira BIF. In order to accommodate Subduction zone signatures of Dhanjori volcanic suite, Alvi and Raza (1992b) has also questioned the northward subduction of the Singhbhum cratonic margin / microplate as suggested by Saha (1994).

A noteworthy feature of the reported chemical data of Malangtoli lavas is low $\mathrm{TiO}_{2}$ concentration (less than $1.5 \%$ ). The $\mathrm{TiO}_{2}$ concentration given by Saha (1994) is much high (in between 1.59 to $2.59 \%$ ). Reported Malangtoli lavas exhibit iron enrichment as compared to high-Mg tholeiite [HMT] and calc-alkaline rocks and in Jensen's cation diagram they are plotted in high-Fe tholeiite [HFT] field (Fig.5c). However, same samples are falling in calc-alkaline field showing iron depletion and enrichment of alkalis in AFM diagram (Fig.5b). This requires explanation.

The authors used discriminant functions (Pearce, 1976) to classify the Malangtoli lavas but they ignored the suggested criteria [particularly $\mathrm{SiO}_{2}$ concentration]. Due to this ignorance andesite samples are plotted in shoshonitic basalt field (Fig.6a). Island arc tholeiite affinity of the Malangtoli lavas can be attributed to a thin active continental margin (Figure 6b) not to a thick rifted continental crust as considered by Saha (1994).

In order to remove misunderstandings of the Singhbhum geology, localized field work and corroborative geochemical data is required. Precise chronological and geochemical data on different volcanic/ magmatic rocks of Singhbhum craton is now available. So, rectification of the field relationships should be the priority to get a well accepted geological model for Singhbhum region.

Jyotishankar Ray, Dept. of Geology, Univ. of Calcutta, replies:

We thank Dr. S.H. Alvi for his keen interest on our paper. Our replies are given below:

Saha (1994) has presented equivalent status for both the Jagan- nathpur and Malangtoli lavas in his generalized chronostratigraphic succession of the Singhbhum-Orissa Iron Ore craton (given in Saha et al., 1988). Similar equivalent early Proterozoic age has been considered for both these two lavas by Bose (2009). Kolhan Group unconformably overlies Malangtoli lavas (Saha 1994; see also Fig 2.3 of Saha, 1994) which we have observed during field work.

Our reported samples of Malangtoli lavas are typically silicaoversaturated (with variable amount of normative quartz) and we reported calc-alkaline nature of them. In a recent paper, Singh et al. (2016) also document a calc-alkaline affinity of Malangtoli.

In the $\mathrm{MgO}-\left(\mathrm{FeO}^{\mathrm{t}}+\mathrm{TiO}_{2}\right)-\mathrm{Al}_{2} \mathrm{O}_{3}$ diagram (Jensen, 1976), the overall calc-alkaline character of reported Malangtoli lavas (as we have documented in our paper) have also been corroborated earlier by Bose (2010, p.120) with a minor spill to tholeiitic side.

S.H. Alvi has rightly pointed out that to remove misunderstanding of the Singhbhum geology, intensive field work and supporting geochemical data is required and for that, we strongly believe that a forum of interested geoscientists should be created at once.

\section{References}

Alvi, S.H. and Raza, M. (1991) Nature and magma type of Jagannathpur volcanic, Singhbhum, Eastern India, Jour. Geol. Soc. India, v.38, pp.524531.

Alvi, S.H. and Raza, M. (1992a) Discovery of Proterozoic boninite from Jagannathpur volcanic suite, Singhbhum craton, Eastern India. Curr. Sci., v.62 (8), pp. 573-574.

Alvi, S.H. and Raza, M. (1992b) Geochemical evidence for the volcanic arc tectonic setting of Dhanjori volcanics, Singhbhum craton, Eastern India. Geol. Mag., v.129 (3), pp. 337-348.

Alvi, S.H. and Raza, M. (2004) Geochemistry and tectonic significance of continental high-Mg andesite (CMA), Jagannathpur volcanic suite, Singhbhum craton, Eastern India. Jour. Appld. Geochem., v.6, pp.15-24.

Banerjee, P.K. (1982) Stratigraphy, petrology and geochemistry of some Precambrian basic volcanic and associated rocks of Singhbhum district of Bihar and Mayurbhanj and Keonjhar districts, Orissa. Mem. Geol. Surv. India, v.111, 58p.

Bose, M.K. (2009) Precambrian mafic magmatism in the Singhbhum craton, eastern India. Jour. Geol. Soc. India., v.73, pp.13-35.

Bose, M.K. (2010) Igneous Petrology. The World Press, Kolkata, 450p.

Dunn, J.A. (1966) Observations on Precambrian stratigraphy of Singhbhum and adjoining areas. In: S. Deb (Ed.) Contributions to Geology of Singhbhum, Jadavpur University Calcutta, pp.15-21.

Jensen, L.S. (1976) A new cation plot for classifying subalkalic volcanic rocks. Ont. Divs. Mines. Misc. Paper No. 66, 22p.

Pearce, J.A. (1976) Statistical analysis of major element patterns in basalts. Jour. Petrol., v.17, pp.15-47.

Saha, A.K., Ray, S.L. and Sarkar, S.N. (1988) Early history of the Earth: evidence from the eastern Indian shield. In: D. Mukhopadhyay (ed), Precambrian of the eastern Indian shield. Mem Geol. Soc. India, no.8, pp.1337.

Saha, A.K. (1994) Crustal evolution of Singhbhum-North Orissa, Eastern India. Mem Geol. Soc. India, no.27, 341p.

Singh, M.R., Manikyamba, C., Ray, J., Ganguly, S., Santosh, M., Saha, A., Rambabu, S. and Sawant, S.S. (2016) Major, trace and PGE geochemistry of Archean Iron Ore Group and Proterozoic Malangtoli metavolcanic rocks of Singhbhum craton, eastern India: Inferences on mantle melting and sulphur saturation history. Ore Geol. Rev., v.72, pp.1263-1289 . 